Published in Internet Archaeology 15 (http://www.inarch.ac.uk/)

\title{
Making space for an archaeology of place
}

\author{
David Wheatley, \\ University of Southampton
}

\section{Abstract}

Rather that attempt to write a balanced or complete overview of the application of GIS to archaeology (which would inevitably end up being didactic and uncritical) this paper sets out to present a discursive and contentious position with the deliberate aim of stimulating further debate about the future role of GIS within our discipline.

To this end, existing applications of GIS to archaeology are reviewed, concentrating on two areas of application, predictive modelling and visibility analyses, and on their wider disciplinary context. It is argued that GIS cannot be simplistically held to have been a 'good thing' or a 'bad thing' for archaeology, but rather that these different application areas may be analysed separately and found to have quite different qualities. Although they are in no sense alternatives to one another, the areas of predictive modelling and visibility analysis can be seen to represent quite different agendas for the development of an archaeology of space and/or place.

The development of correlative predictive models is considered first, both from the perspective of explanation and of cultural resource management. The arguments against predictive modelling as a means of explanation are rehearsed and it is found to be overgeneralising, deterministic and de-humanised. As a consequence, it is argued that predictive modelling is now essentially detached from contemporary theoretical archaeological concerns. Moreover, it is argued to be an area with significant unresolved methodological problems and, far more seriously, that it presents very real dangers for the future representativity of archaeological records.

Second, the development of GIS-based visibility analysis is reviewed. This is also found to be methodologically problematic and incomplete. However, it is argued that visibility 
studies - in direct contrast with predictive modelling - have remained firmly situated within contemporary theoretical debates, notably about how human actors experience places (phenomenology) and perceive their surroundings (cognition). A such, it is argued that visibility analysis has the potential to continue to contribute positively to the wider development of archaeological thinking, notably through laying the foundations of a human-centred archaeology of space.

The paper concludes by qualifying the claim that there is a 'hidden agenda' for archaeological applications of GIS (Wheatley 1993), particularly by making it clear that this does not imply an attempt to distort the discipline. Instead, this is explained in terms of institutional and disciplinary inertia that should be addressed through greater debate and communication over these issues.

\section{GIS, a non-novel compound technology}

GIS has been ubiquitous in archaeological research and management for some ten years or more now. For an applied technology, it has generated an unprecedented level of interest and spawned a large number of projects both in the research context and also in the arena of cultural resource management. At least five edited volumes (Aldenderfer and Maschner 1996, Allen, Green, and Zubrow 1990, Lock 2000, Lock and Stancic 1995, Maschner 1996, Westcott and Brandon 2000), one book (Wheatley and Gillings 2002) and countless papers in journals and proceedings volumes have been dedicated to this single technological area marking it out as probably the most discussed area of computer technology there has ever been in archaeology.

Despite this, Geographic Information Systems (GIS) are not remotely revolutionary in technical terms. This is because GIS are not single technologies in the sense that they depend on one novel innovation to define them. Instead, they are comprised of a variety of hardware and software components packaged together and provided with a convenient label. At present, what we refer to as 'a GIS' normally consists of (a) a special kind of database that integrates physical, attribute and topological information; (b) a set of procedures for manipulating that database including input, output and what we might call 'midput' (production of new data within the system) and (c) an interface that allows 
rational human beings to use (a) and (b) in a productive way without extensive training. There is (and has never been) anything magic about the label that we choose to give to this particular re-combination of components that, in this case, derive from other software areas such as computer-aided mapping, computer-aided design, database management systems and image processing.

In fact, the most extraordinary thing about GIS has been that it has been so successful without it being a significant technological innovation. Most computer scientists have never shown significant interest in GIS and many are openly baffled by the popularity of a technology that appears, to them, to be nothing but a re-application of existing, sometimes even outdated, components. By contrast, archaeologists and geographers have sometimes seemed to reify GIS to the extent that they claim that it has changed their academic disciplines forever.

In a sense, then, GIS has always been 'beyond technology' because they are more important for what they can do than what they are. What they can do, I have argued elsewhere, is give us the freedom to begin to construct an 'archaeology of place' (Wheatley 2000): a body of theory and method that permits us to explore the meaningful spatial configuration of archaeological remains. 'Meaningful' is the key distinction between an archaeology of place and what Clarke termed 'Spatial Archaeology' (Clarke 1977) because it acknowledges that the spatial organisation of materials depends on the meaningful actions of knowledgeable agents, and that the larger scale patterns that we observe in the archaeological record are the products of the intended and unintended consequences of these human actions (Giddens 1984).

With this 'mission statement' in mind, it is worth reviewing the applications of GIS to archaeology up to the present time, in order to understand something of the wider relevance of GIS for archaeological theory and practice.

\section{Archaeology and GIS}

GIS has, to date, been primarily applied to 'landscape studies' (although for exceptions see e.g. (Huggett 2000, Miller 1996, Vullo, Fontana, and Guerreschi 1999). In the context 
of GIS this generally refers to archaeological analysis undertaken at a regional or intersite scale ${ }^{1}$ as distinct from an intra-site scale (Crumley and Marquardt 1990, Zubrow 1990), and these kinds of studies have formed the mainstay of the published applications of GIS for a decade, usually making use of existing, sometimes published, data which has often been collected with other purposes and other analytical methods in mind.

Within this there have also been a number of different methodological approaches developed. These include 'classical' spatial archaeology approaches such as geometric spatial-allocation models, trend surface and site catchment analysis (Vita-Finzi and Higgs 1970) originally introduced to archaeology by the 'new archaeology' (Clarke 1968, Clarke 1972), and latterly perpetuated using GIS (see e.g. Ruggles and Church 1996, Savage 1990 for spatial allocation, Kvamme 1990c, Neiman 1997 for trend surface and Gaffney and Stancic 1991, Hunt 1992 for site catchment analyses). These have been rediscovered and re-applied to contemporary archaeological situations, and sometimes 'improved' through the application of increased processing capacities or algorithms. GIS has also permitted further advances in the use of classical statistical approaches to archaeological materials, notably by encouraging the use of one sample significance tests (Kvamme 1990b) and, more recently, for the application of geostatistical approaches to spatial variables (Ebert 1998, Robinson and Zubrow 1999)

Two areas of application stand out, however, as together representing the largest number of published applications of GIS to archaeology. These are predictive modelling and visibility (sometimes 'viewshed') analysis. In a sense, these can be seen to represent entirely different approaches to the application of spatial technology to archaeological problems and, more relevant to this discussion, to have quite different agendas for the development of an archaeology of spaces and/or places.

\footnotetext{
${ }^{1}$ We should note that, although it is used uncritically within the GIS literature, 'landscape' is far from an unproblematic concept. See e.g. Thomas, J. 1993. "The politics of vision and the archaeologies of landscape," in Landscape: politics and perspectives. Edited by B. Bender, pp. 19-48. London: Berg., and other papers in Bender, B. Editor. 1993. Landscape: politics and perspectives. Explorations in anthropology. London: Berg..
} 


\section{Inductive, correlative predictive modelling}

Inductive, correlative predictive modelling aims to predict the archaeological characteristics of places from their non-archaeological - usually environmental characteristics (Kvamme 1990a). It is usually undertaken by using the statistical properties of locations in which sites occur to generate a classification rule that determines the archaeological characteristics of locations for which the archaeological properties are not known. A wide variety of specific methods have been used for this, of which Logistic Regression has become the most widespread (Warren 1990).

This kind of predictive modelling may be done for two main reasons: (a) to explain the observed spatial distribution of archaeological remains, and hence the behaviour of past communities or (b) to inform archaeological management strategies. Predictive modelling represents, by some way, the largest group of publications in the archaeological GIS literature and its use has generated some of the most heated debate both at conferences and in print. Given this debate surrounding the use of predictive modelling (see e.g. Ebert 2000, Gaffney and van Leusen 1995, Kvamme 1997, Wheatley 1993, Wheatley 1998), it may seem unnecessary to persist in development an explicit critique.

Several things, however, argue strongly for the need for further critical debate about the continuing dominance of predictive modelling within the archaeological GIS world. The first reason is that although much has been written about the theoretical issues surrounding explanatory predictive modelling, rather less attention has been directed to the reasons why cultural resource managers should be wary of predictive models. As a direct result of failure to communicate the debate about predictive models, and despite the obvious reservations of many archaeologists the funding for predictive modelling projects in cultural resource management agencies is increasing rapidly, leading to a proliferation of correlative predictive modelling projects that frequently ignore the published concerns of many archaeologists.

The second reason is a personal one, and that is that while I have frequently been seen as a critic of predictive modelling - despite having actually published a case study in its use (Wheatley 1996a) - I have never systematically outlined my objections to it in print. 


\section{Predictive modelling as a form of explanation}

Within the GIS community, and in the literature, a great deal of attention has been devoted to the theoretical issues inherent in the use of correlative predictive models as a form of archaeological explanation. This has concentrated on the problems of 'ecological fallacy' or 'environmental determinism'. Although the latter is a highly contested term that should probably now be deprecated (Kvamme 1997), the central accusations have never been properly answered.

These are, firstly, that to explain the past by asserting the primacy of correlations between behaviour and environmental characteristics is reductionist to the extent that it effectively de-humanises the past. The meaningful human actors that we are seeking to understand are reduced to automata who behave according to a rule that connects their behaviour to their environment. This is not to deny that correlative predictive models may be telling us something about the behaviour of people in the past, but the methodology directs us to a particular very small range of behaviours by systematically excluding anything that cannot be expressed as a statistical correlation between mapped variable and archaeological record. Correlative prediction as a form of explanation therefore purports to explain the spatial configuration of the archaeological record while at the same time constraining that explanation a priori to the kinds of things that a functional-processual school of theory would like to be explanatory.

Secondly, correlative prediction as a form of explanation is profoundly anti-historical. It assumes that the patterns we observe are wholly a product of the immediate surroundings of the individuals and communities responsible for them and can therefore be explained by some link between the two. In reality, the behaviour and activities that structure the spatial patterns in archaeological landscapes are just as much a product of historical as contemporary factors. Spaces may be abstract, geometric and synchronous but places have histories and biographies as well and it is places that are inhabited by meaningful human actors.

A third problem is that correlative prediction ignores the critical theoretical space that lies between past people's behaviours and their physical surroundings. It effectively 
substitutes a mathematical equation for the meaningful bit of human actions. To many contemporary archeaeologists, the physical environment directly contributes little to the behaviour of individuals whose relationship with the physical world is mitigated through the social world, best understood by concepts such as 'habitus' (Bourdieu 1977) or 'structuration' (Giddens 1984). Even archaeologists who are not explicitly concerned with social theory recognise that the behaviour of human beings is not simply produced automatically from environmental stimuli. To understand this does not require us to subscribe to some single theoretical notion and a diverse range of theories have actually been invoked to address this, ranging from Gibson's theories of ecological perception (Llobera 1996) through to phenomenology (Tilley 1994).

Correlative predictive modelling as a form of explanation has therefore been rejected not only by some 'avant-garde' group of postmodern theorists, but by the majority of archaeologists at work today. As such, the only real defence of the considerable effort that is currently being expended on the development of correlative predictive models is that they have some pragmatic utility for the management of archaeological resources. In other words:

“... because such models are aimed at the effective protection of the cultural (archaeological) heritage rather than its understanding ... a different set of rules should apply ... essentially sanctioning the ED (environmentally deterministic) approach for practical reasons. In particular, it should be perfectly valid to try to hunt down environmental correlates of settlement location ... so long as no simplistic causal 'explanation' is attached to these correlations." Van Leusen, (Gaffney and van Leusen 1995).

\section{Predictive modelling for resource management}

Predictive modelling for solely management reasons is itself a theoretically questionable aim, with many archaeologists from both areas of the discipline finding the idea that it is possible to manage archaeology without understanding it highly problematic (Gaffney and van Leusen 1995). However, even if we set these concerns aside then the use of correlative predictive models may still be found to be a highly undesirable way to 
proceed. The main issues might be argued to be that (a) it doesn't actually work very well, (b) the results are rarely used and (c) that if it did work, and the results were used, then it would be likely to be highly detrimental to the recorded archaeological resource. These claims, obviously, require some enlargement.

\section{It doesn't actually work very well}

There are many methodological problems with the most popular statistical procedures for generating predictive models (see (Woodman and Woodward 2002) for an excellent discussion) but the most serious issue is probably that most practitioners make no attempt to find out how well their models actually perform. To do so requires that the predictions of the model be compared with the archaeological resource (or at least an unbiased sample of it) and the only way to do this, of course, is to collect more archaeological data. This represents something of a 'catch 22 ' for predictive modelling, because data collection is precisely the activity that most model-builders are usually trying to avoid. Consequently, instead of finding out how well the model predicts undiscovered archaeology, models are evaluated as to how well they predict their own data, and measures such as 'gain statistics' (Kvamme 1992) are offered. These are not measures of the performance of the model, because if it means anything, 'performance' must mean the extent to which the model predicts undiscovered archaeology. Instead, these are measures of the extent to which the model is internally consistent. Gain (and similar) statistics are widely touted as the former, however:

"Another way to assess the performance of a predictive model is to measure its gain in accuracy over a random or null classification”. (Warren and Asch 2000)

The use of these statistics, and attempts to 'pass them off' as performance measures also cannot hide the fact that the gain of most published predictive models is - by any rational estimation - not very good. Regression models typically produce correlation coefficients of $25-30 \%$, or gain statistics around 60-70\%. In short, models simply do not perform at a level that is very useful either for explanation or management purposes. 


\section{It isn't used}

There is little point to developing a model that is not connected to some consequential management action and, in this respect, there are to date very few instances in which development plans or archaeological mitigations have actually been altered on the basis of a statistical prediction of archaeological characteristics. In the case of development control, there is often a need (and sometimes a legal requirement) to look for archaeology on the ground whether the model predicts archaeology or not. This, of course, provides for a strangely biased sample of the archaeological record because we are only looking for archaeological materials where development takes place. It is still probably better than the alternative, which is to actually use the model to decide how we should look for archaeological resources.

\section{It shouldn't be used}

If models were actually used - in other words resource management proceeded by (i) generating a predictive model and then (ii) using it to influence where we look for undiscovered archaeology - then we would effectively have created a self-fulfilling sampling strategy. To understand why this is, we need only realise that any model that is based on the known distribution of archaeological sites is actually an embodiment of the visibility, bias and historical accidents that have formed that record. Such a model is therefore predicting the bias in the known record. Using such a model effectively means that we are systematically looking harder for undiscovered sites where we expect to find them (this is shown diagrammatically in Figure 1). Some practitioners might argue that it is necessary to look in the places where the model does not predict archaeology as well as where it does, but it remains true that any management outcome that leads archaeologists to look harder or more frequently in those locations where the model predicts archaeology is a self-fulfilling feedback system that will lead to an increasingly unrepresentative archaeological record (Figure 2).

In the most extreme case, archaeologists would no longer bother to look for new archaeological sites in those locations where the model predicted zero probability of undiscovered archaeology, effectively creating a model with no potential to revise itself. 


\section{A negative conclusion and a positive suggestion}

Archaeology should really face up to the possibility that useful, correlative predictive modelling will never work because archaeological landscapes are too complex or, to put it another way, too interesting. It is obviously unrealistic for financial reasons to expect archaeological investigations to be done everywhere, but generating correlative models that do not work and should not be used is not the answer to the dilemma of how to best deploy scarce archaeological effort. This is undeniably a very negative conclusion to reach and it would be reasonable to expect that some more positive suggestions should accompany it: if predictive modelling is of no value in helping us address a real concern within resource management, then what is?

To answer this, we should consider the functional requirement for building a model in archaeological resource management. The reason most often cited for its use is that there are insufficient financial resources to conduct detailed archaeological work everywhere and given this, predictive modelling is an attractive solution. However, it has been argued above that correlative predictive modelling does not actually work very well, and more significantly will lead to an increasingly unrepresentative archaeological record. If resource management requires a methodology that does work, will lead to a more representative record then it follows from this that archaeology would be better served by a focus on well-designed and properly implemented sampling strategies, rather than correlative predictive models.

\section{Visibility studies}

Viewshed analysis is starting to become so routine that Aldenderfer has suggested it is now a viable alternative to thinking about the past (Aldenderfer 1996). It aims to substantively explore the relationships of visibility and intervisibility between particular archaeological locations in the landscape. Contrary to popular belief, this kind of analysis pre-dates GIS by at least two decades, with both formal studies such as Renfrew and Fraser's work on Orkney (Fraser 1983, Renfrew 1979) and anecdotal discussions about visual impressiveness or placement of monuments. The widespread availability of digital tools for modelling and quantifying visibility provided significant impetus to this research 
area providing, for the first time, the ability to calculate indices such as area-of-view and angle-of-view rapidly for many sites. As such, 'viewshed analysis' need not fear the accusation, often levelled at it at conferences and implied in Aldenderfer's remark, that it is a form of technological determinism with no archaeological research agenda.

The formal analysis of visibility presents as many - if not more - methodological obstacles as predictive modelling. These have been discussed elsewhere (Gillings and Wheatley 2001, Wheatley and Gillings 2000) but a non-exhaustive list of significant methodological problems would include issues of reciprocity (Loots 1997), the quality of DEM data (and it's influence on visibility), the effects of vegetation, the modelling of probable and fuzzy viewsheds (Fisher 1991, Fisher 1992, Fisher 1994, Fisher 1995, Fisher 1996) and the availability of suitable hardware and software to calculate the desired indices of visibility or 'inherent visibility' (Lake, Woodman, and Mithen 1998).

The key reason why visibility analysis can be argued to be a significant positive contribution to archaeology is that it is a form of analysis that begins from a model of the field of vision of human actors within a landscape. From this human-scale component, generalisations and quantifications are built and methodologies developed. Of course, computer models are not perfect representations of either human perception or the landscape, and visibility is not the only sense implicated in the human experience: sound, smell, feeling or even taste might also be amenable to substantive analysis (Gillings and Goodrick 1996), although only sound has so far been significantly investigated (Watson 1999). But pointing out that visibility analysis is not complete is not the same as arguing that it is inherently defective. Viewshed analyses begin from the human-scale experience of existing in the physical and social world. As such, they contribute to the formulation of substantive approaches to issues as diverse as cognitive perception, culture/nature dichotomy, visualism and sensory primacy, temporality and directionality. This is why viewshed analysis has so effectively resonated with many of the criticisms of unreformed functional-processual spatial archaeology, while at the same time offering a real, substantive alternative to relativist positions such as phenomenology. 
There has undoubtedly been work that seems to be aimlessly calculating viewsheds for no obvious reason (other than that there is a button available to do GIS-based visibility analysis). But this area of GIS applications has also produced interesting findings in understanding the patterns of relationships between Neolithic and bronze age monuments in Wessex (Wheatley 1995, Wheatley 1996b) and in Scotland (Fisher et al. 1997), the locations of petroglyphs (Bradley 1991), symbolic astronomy (Ruggles and MedyckyjScott 1996, Ruggles, Medyckyj-Scot, and Gruffydd 1993) and Helenistic defence systems (Loots, Knackaerts, and Waelkens 1999).

Visibility analysis, and similar human-centred forms of analysis, need to mount a more vigorous defence of their rationale than have been available to date. Not only can visibility analysis claim to be significantly rooted in recent intellectual debates within archaeology and related disciplines, but it can also point to methodological developments and archaeological results that set it apart as the most promising current area of application for GIS technologies.

\section{Archaeological GIS reconsidered: what is the 'hidden agenda'?}

We might learn one significant lesson from this comparison: that disciplinary context is highly significant in the success of failure of a wider methodological project. From this we might therefore argue that if we are to continue developing interesting applications of GIS to archaeology we should take greater account of the professional and intellectual conditions into which it is to be applied.

In simple terms, it has been argued that predictive modelling (in the restricted sense of correlative predictive models of archaeological site location) has not been successful because it is isolated from wider theoretical concerns within the discipline, while visibility analysis, albeit with significant unresolved methodological problems, has shown that it articulates with a wide range of current concerns. This is, it is acknowledged, something of an extreme position and certainly a simplification but it is also one that is necessary for the purposes of debate and in order to try and ensure that it is an 
archaeological agenda that determines the ways in which archaeological applications of spatial technologies may develop ${ }^{2}$.

That it is apparently not an archaeological agenda that has determined the extent to which effort is expended on different application of spatial technologies led to the conclusion that there was, in some sense, a 'hidden agenda' behind the use of GIS for archaeology (Wheatley 1993). This terminology carries with it connotations of deliberate activities to 'pervert' archaeology from some 'true path' that were not intended and, as a result, it is necessary to clarify what was meant by the term.

Institutions carry with them a certain intellectual and social momentum that cannot be easily overcome. In the case of archaeology, many of the theoretical ideas that prevailed in the 1960s and 1970s are embodied in the practices, routines and even legislation of our social and professional institutions. This is rarely a real problem, as most ideas remain appropriate and unproblematic and, if they change at a rate at which institutions can keep up with them then our practices and our theories remain broadly synchronised. But in some cases, our ways of thinking about the past change sufficiently quickly that those that are embodied in our institutions rapidly lose their currency, and sometimes ideas that have been rejected by the majority of archaeologists remain on the agenda within universities, archaeological units or government agencies simply because of this institutional momentum. It is in this context that I see the issue of an 'agenda' (hidden or not) for archaeological applications of GIS. I do not claim that there is a sinister group of functional-processual archaeologists meeting in secret to determine how archaeological funding is allocated to different application areas of GIS, but I do think it is possible to see that how routinized practices and institutional issues such as heritage legislation in

\footnotetext{
${ }^{2}$ These kinds of critical, debating papers have been criticised by e.g.Kvamme, K. L. 1997. Ranters corner: bringing the camps together: GIS and ED. Archaeological Computing Newsletter 47:1-5. as unduly negative in their conclusions, and also likely to divide the 'GIS community'. But a research community is not a football team in which it is beneficial to conceal differences for the greater good, rather it is healthy to promote and debate different viewpoints and perspectives.
} 
which spatial archaeology is developing might have an impact on how we determine what are the most productive ways to explore the past.

If we want to take control of the agenda, we need to engage with our institutions and seek to change our practices in such a way as to make them more aware of contemporary ways of thinking. This can be achieved by communicating new ideas more effectively both to fellow practitioners within archaeology, and also to the politicians and civil servants who frame legislation and ultimately determine archaeological practice. This might involve political and practical as well as intellectual action, but if we can overcome this inertia, and take control of our own agenda, it would allow us far greater freedom to develop an archaeology of space that is informed by current theoretical thinking.

This is not to say that we must be committed to some single philosophical school or subscribe to whichever social theorist is currently fashionable - on the contrary, greater theoretical diversity, pluralism and debate would be most welcome - but it does suggest that continuing to plough our energies into developing ever more expensive projects to create inductive, correlative predictive models is not only going to be detrimental to the future representativity of the archaeological record, but stands in direct opposition to this aim.

\section{References}

Aldenderfer, M. 1996. "Introduction," in Anthropology, space and geographic information systems, Spatial information series. Edited by M. Aldenderfer and $\mathrm{H}$. D. G. Maschner, pp. 3-18. New York: Oxford University Press.

Aldenderfer, M., and H. D. G. Maschner. Editors. 1996. Anthropology, space and geographic information systems. Spatial information series. New York: Oxford University Press.

Allen, K., S. Green, and E. B. W. Zubrow. Editors. 1990. Interpreting space: GIS and archaeology. London: Taylor \& Francis.

Bender, B. Editor. 1993. Landscape: politics and perspectives. Explorations in anthropology. London: Berg. 
Bourdieu, P. 1977. Outline of a theory of practice. Vol. 16. Cambridge studies in social anthropology. Cambridge: Cambridge University Press.

Bradley, R. 1991. Rock art and the perception of landscape. Cambridge Archaeological Journal 1:77-101.

Clarke, D. L. 1968. Analytical Archaeology. London: Methuen.

—. Editor. 1972. Models in Archaeology. London: Methuen.

—. 1977. Spatial archaeology. London: Academic Press.

Crumley, C. L., and W. H. Marquardt. 1990. "Landscape: a unifying concept in regional analysis," in Interpreting space: GIS and archaeology. Edited by K. M. S. Allen, S. W. Green, and E. B. W. Zubrow. London: Taylor \& Francis.

Ebert, D. 1998. Expanding the Selection of Tools for Spatial Analysis: Geostatistics and the Als Feildwalking Data. M.Sc., University of Southampton.

Ebert, J. I. 2000. "The state of the art in "inductive" predictive modeling: seven big mistakes (and lots of smaller ones)," in Practical applications of GIS for archaeologists: a predictive modeling kit. Edited by K. L. Westcott and R. J. Brandon, pp. 129-134. London: Taylor \& Francis.

Fisher, P. 1991. First experiments in viewshed uncertainty: the accuracy of the viewshed area. Photogrammetric Engineering and Remote Sensing 57:1321-1327.

—. 1992. First experiments in viewshed uncertainty: simulating fuzzy viewsheds.

Photogrammetric Engineering and Remote Sensing 58:345-352.

—. 1994. "Probable and fuzzy models of the viewshed operation," in Innovations in GIS. Edited by M. Worboys, pp. 161-175. London: Taylor \& Francis.

—. 1995. An exploration of probable viewsheds in landscape planning. Environment and Planning B: Planning and Design 22:527-546.

- 1996. Reconsideration of the viewshed function in terrain modelling. Geographical Systems 3:33-58. 
Fisher, P., C. Farrelly, A. Maddocks, and C. Ruggles. 1997. Spatial analysis of visible areas from the Bronze Age cairns of Mull. Journal of Archaeological Science 24:581-592.

Fraser, D. 1983. Land and Society in Neolithic Orkney. Vol. British Series 117. Oxford: British Archaeological Reports.

Gaffney, V., and Z. Stancic. 1991. GIS approaches to regional analysis: a case study of the island of Hvar. Ljubljana: Filozofska fakulteta.

Gaffney, V., and M. van Leusen. 1995. "Postscript - GIS, environmental determinism and archaeology: a parallel text," in Archaeology and geographical information systems: a European perspective. Edited by G. R. Lock and Z. Stancic, pp. 367382. London: Taylor \& Francis.

Giddens, A. 1984. The constitution of society: outline of the theory of structuration. Cambridge: Polity press.

Gillings, M., and G. T. Goodrick. 1996. Sensuous and reflexive GIS: exploring visualisation and VRML. Internet Archaeology 1.

Gillings, M., and D. Wheatley. 2001. "Seeing is not believing: unresolved issues in archaeological visibility analysis," in On the good use of geographic information systems in archaeological landscape studies, COST Action G2. Edited by B. Slapsak, pp. 25-36. Brussels: European Union EUR19708.

Huggett, J. 2000. "Looking at intra-site GIS," in CAA96 computer applications and quantitative methods in archaeology, vol. BAR International Series 845. Edited by K. Lockyear, T. J. T. Sly, and V. Mihailescu-Birliba, pp. 117-122. Oxford: Archaeopress.

Hunt, E. D. 1992. Upgrading site-catchment analyses with the use of GIS: investigating the settlement patterns of horticulturalists. World Archaeology 24:283-309.

Kvamme, K. L. 1990a. "The fundamental principles and practice of predictive archaeological modelling," in Mathematics and information science in 
archaeology: a flexible framework, vol. 3, Studies in modern archaeology. Edited by A. Voorips, pp. 257-295. Bonn: Holos-Verlag.

—.1990b. One-sample tests in regional archaeological analysis: new possibilities through computer technology. American Antiquity 55:367-381.

—. 1990c. Spatial autocorrelation and the Classic Maya Collapse revisited: refined techniques and new conclusions. Journal of Archaeological Science 17:197-207.

-. 1992. A predictive site location model on the high plains: an example with an independent test. Plains Anthropologist 37:19-40.

—. 1997. Ranters corner: bringing the camps together: GIS and ED. Archaeological Computing Newsletter 47:1-5.

Lake, M. W., P. E. Woodman, and S. J. Mithen. 1998. Tailoring GIS software for archaeological applications: an example concerning viewshed analysis. Journal of Archaeological Science 25:27-38.

Llobera, M. 1996. Exploring the topography of mind: GIS, social space and archaeology. Antiquity 70:612-622.

Lock, G. R. Editor. 2000. Beyond the map: archaeology and spatial technologies, 321 edition. NATO Science Series A: Life Sciences. Amsterdam: IOS Press.

Lock, G. R., and Z. Stancic. Editors. 1995. Archaeology and geographical information systems: a European perspective. London: Taylor \& Francis.

Loots, L. 1997. The use of projective and reflective viewsheds in the analysis of the hellenistic defence system at Sagalassos. Archaeological Computing Newsletter 49:12-16.

Loots, L., K. Knackaerts, and M. Waelkens. 1999. "Fuzzy Viewshed Analysis of the Hellenistic City Defence System at Sagalassos, Turkey," in Archaeology in the Age of the Internet: CAA97, 750 edition, BAR International Series. Edited by L. Dingwall, S. Exon, V. Gaffney, S. Laflin, and M. van Leusen, pp. 82 [CD-ROM]. Oxford: Archaeopress. 
Maschner, H. D. G. Editor. 1996. New methods, old problems: geographical information systems in modern archaeological research. CIA Occasional Paper No. 23. Carbondale, Ilinois: Southern Illinois University at Carbondale.

Miller, A. P. 1996. "Digging deep: GIS in the city," in Interfacing the past, 28 edition, vol. 2, Analecta Praehistorica Leidensa. Edited by H. Kammermans and K. Fennema, pp. 369-376. Leiden: Leiden University Press.

Neiman, F. D. 1997. "Conspicuous consumption as wasteful advertising: a Darwinian perspective on spatial patterns in Classic Maya terminal monuments dates," in Rediscovering Darwin: Evolutionary theory and archaeological explanation, vol. 7, Archaeological Papers of the American Anthropological Association. Edited by M. C. Barton and G. A. Clark, pp. 267-290.

Renfrew, C. 1979. Investigations in Orkney. London: Society of Antiquaries.

Robinson, J. M., and E. Zubrow. 1999. "Between spaces: interpolation in archaeology," in Geographic information systems and landscape archaeology, vol. 3, The archaeology of Meditteranean landscapes. Edited by M. Gillings, D. Mattingly, and J. van Dalen, pp. 65-83. Oxford: Oxbow Books.

Ruggles, C., and R. L. Church. 1996. "Spatial allocation in archaeology: an opportunity for reevaluation," in New methods, old problems: Geographic Information Systems in modern archaeological research, CAI Occasional Paper 23. Edited by H. D. G. Maschner, pp. 147-173. Carbondale, Ilinois: Southern Illinois University at Carbondale.

Ruggles, C., and D. J. Medyckyj-Scott. 1996. "Site location, landscape visibility and symbolic astronomy: a Scottish case study," in New methods, old problems: Geographic Information Systems in modern archaeological research, Occasional Paper No. 23. Edited by H. D. G. Maschner, pp. 127-146. Carbondale, Ilinois: Southern Illinois University at Carbondale.

Ruggles, C. L. N., D. J. Medyckyj-Scot, and A. Gruffydd. 1993. "Multiple viewshed analysis using GIS and its archaeological application: a case study in northern 
Mull," in Computing the past: computer applications and quantitative methods in archaeology - CAA 92. Edited by J. Andresen, T. Madsen, and I. Scollar, pp. 125132. Aarhus: Aarhus University Press.

Savage, S. H. 1990. "Modelling the Late Archaic social landscape," in Interpreting space: GIS and Archaeology. Edited by K. M. S. Allen, S. Green, and E. B. W. Zubrow, pp. 330-335. London: Taylor and Francis.

Thomas, J. 1993. "The politics of vision and the archaeologies of landscape," in Landscape: politics and perspectives. Edited by B. Bender, pp. 19-48. London: Berg.

Tilley, C. 1994. A phenomenology of landscape: places, paths and monuments. Explorations in Archaeology. Oxford: Berg.

Vita-Finzi, C., and E. Higgs. 1970. Prehistoric Economy in the Mount Carmel area of Palestine: site catchemnt analysis. Proceedings of the Prehistoric Society 36:1-37.

Vullo, N., F. Fontana, and A. Guerreschi. 1999. "The application of GIS to intra-site spatial analysis: preliminary results from Alpe Veglia (VB) and Mondeval de Sora (BL), two Mesolithic sites in the Italian Alps," in New Techniques for Old Times: CAA98, British Archaeological Reports International Series 757. Edited by J. A. Barcelo, I. Briz, and A. Vila, pp. 111-116. Oxford: Archaeopress.

Warren, R. E. 1990. "Predictive modelling of archaeological site location: a primer," in Interpreting space: GIS and archaeology. Edited by K. M. S. Allen, S. W. Green, and E. B. W. Zubrow. London: Taylor \& Francis.

Warren, R. E., and D. L. Asch. 2000. "A predictive model of archaeological site location in the eastern Prairie Peninsula," in Practical applications of GIS for archaeologists: a predictive modeling kit. Edited by K. L. Westcott and R. J. Brandon, pp. 5-32. London: Taylor \& Francis.

Watson, A. 1999. Architecture and sound: an acoustic analysis of megalithic monuments in prehistoric Britain. Antiquity 27:467-470. 
Westcott, K. L., and R. J. Brandon. Editors. 2000. Practical applications of GIS for archaeologists: a predictive modeling kit. London: Taylor \& Francis.

Wheatley, D. 1993. "Going over old ground: GIS, archaeological theory and the act of perception," in Computing the past: computer applications and quantitative methods in archaeology - CAA 92. Edited by J. Andresen, T. Madsen, and I. Scollar, pp. 133-138. Aarhus: Aarhus University Press.

—. 1995. "Cumulative viewshed analysis: a GIS-based method for investigating intervisibility, and its archaeological application," in Archaeology and geographic information systems: a European perspective. Edited by G. Lock and Z. Stancic, pp. 171-185. London: Taylor \& Francis.

—. 1996a. "Between the lines: the role of GIS-based predictive modelling in the interpretation of extensive field survey," in Interfacing the past, 28 edition, vol. 2, Analecta Praehistorica Leidensa. Edited by H. Kammermans and K. Fennema, pp. 275-292. Leiden: Leiden University Press.

—. 1996b. "The use of GIS to understand regional variation in Neolithic Wessex," in New methods, old problems: Geographic Information Systems in modern archaeological research, No. 23 edition, CAI Occasional Paper. Edited by H. D. G. Maschner, pp. 75-103. Carbondale, Ilinois: Southern Ilinois University at Carbondale.

—. 1998. Ranters corner: keeping the camp fires burning: the case for pluralism. Archaeological Computing Newsletter 50:2-7.

—. 2000. "Spatial technology and archaeological theory revisited," in CAA96 computer applications and quantitative methods in archaeology, vol. BAR International Series 845. Edited by K. Lockyear, T. J. T. Sly, and V. Mihailescu-Birliba, pp. 123-131. Oxford: Archaeopress.

Wheatley, D., and M. Gillings. 2000. "Vision, perception and GIS: developing enriched approaches to the study of archaoelogical visibility," in Beyond the map: 
archaeology and spatial technologies, 321 edition, NATO Science Series A: Life Sciences. Edited by G. R. Lock, pp. 1-27. Amsterdam: IOS Press.

—.2002. Spatial technology and archaeology: a guide to the archaeololgical applications of GIS. London: Taylor and Francis.

Woodman, P. E., and M. Woodward. 2002. "The use and abuse of statistical methods in archaeological site location modelling," in Contemporary themes in archaeological computing, No. 3 edition, University of Southampton Department of Archaeology Monograph. Edited by D. Wheatley, G. Earl, and S. Poppy, pp. 39-43. Oxford: Oxbow.

Zubrow, E. B. W. 1990. "Contemplating space: a commentary of theory," in Interpreting space: GIS and archaeology. Edited by K. M. S. Allen, S. W. Green, and E. B. W. Zubrow, pp. 67-72. London: Taylor \& Francis. 


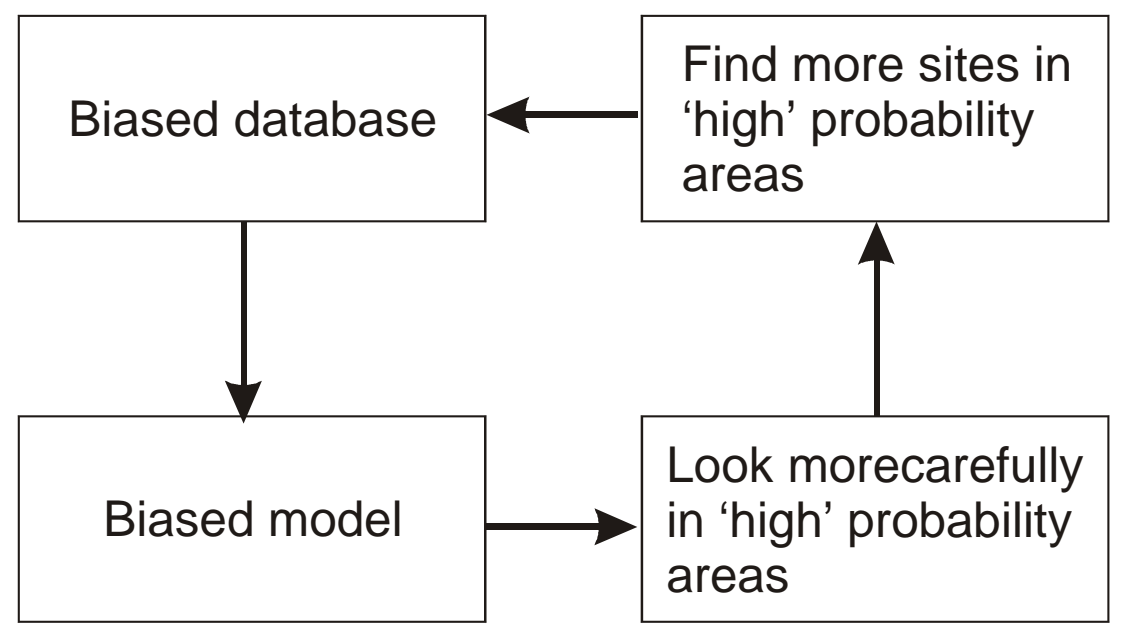

Figure 1. A positive feedback in which a biased model causes archaeologists to behave as to look more closely at areas already identified as having more sites, thus reinforcing the bias in the original model.

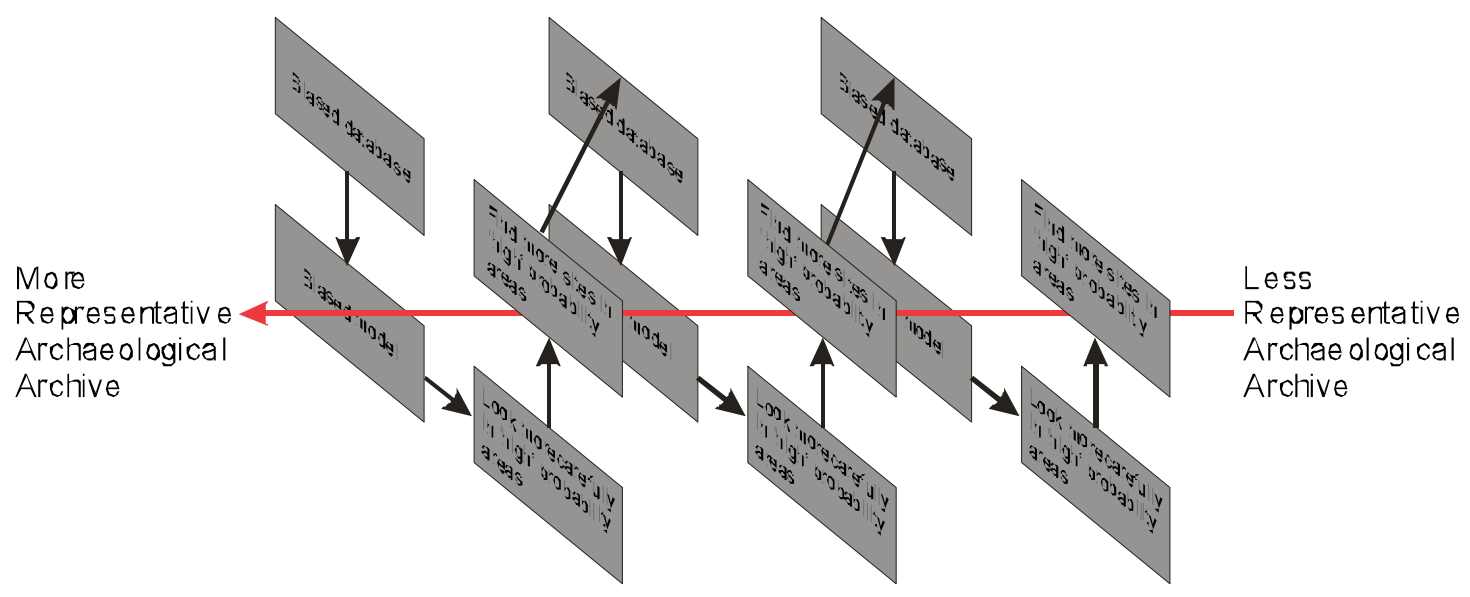

Figure 2. The feedback look repeats itself through time, ensuring that each iteration of a predictive model leads to an even more unrepresentative database of archaeological materials. 